\title{
日射量による昼光照度の推定方法に関する研究 \\ A METHOD FOR THE ESTIMATION OF THE SOLAR ILLUMINANCE BASED UPON THE SOLAR IRRADIANCE
}

\author{
井川憲 男*, 島崎 佐智代**, 中村 洋*** \\ Norio IGAWA, Sachiyo SHIMASAKI and Hiroshi NAKAMURA
}

\begin{abstract}
The solar irradiance and illuminance are important as meteorological data to predict indoor environment. However, the data concerning the daylight are not measured at the ordinary meteorological stations. The horizontal global irradiance is normally measured in the meteorological stations in Japan. The luminous efficacy, by which the irradiance can be converted into the illuminance, is essential for obtaining fundamental daylight data for the prediction of the daylit environment. The luminous efficacy has been investigated for a long time in the world. Several considerations have been put forward. But the sufficient theories on the luminous efficacy have not established yet. The relations between the diffuse irradiance and the diffuse illuminance, the direct normal irradiance and the direct normal illuminance, and the horizontal global irradiance and the horizontal global illuminance were examined and discussed based on the data acquired at the measurement of the IDMP station operated by the authors. The results of the examination are stated and the equations newly proposed by the authors on the luminous efficacies are introduced in this paper.
\end{abstract}

Keywords: Luminous efficacy, Irradiance, Daylight illuminance 発光効率、日射量、昼光照度

\section{1. はじめに}

室内の環境予測には、気象データが必須である。その中でも日射 や昼光に関するデータは重要な基礎資料である。一般の気象台では 日射の測定は行っているが、昼光に関する測定はほとんど行ってい ない。最近、二宮、赤坂らは、国内各所の AMeDAS の長期連続測 定データを有効に活用し、AMeDAS の限られた測定項目から、熱 負荷計算などに利用できる項目を推定し、全国約 840 地点の日射を 含む気象データを作成している ${ }^{1,2,3}$ 。

このような気象台で取得された日射（太陽放射）のデータや日射 に関する気象データを昼光環境の予測や評価に適用するには、日射 量（太陽放射照度）を昼光照度に変換しなければならない。それに は発光効率が有用である。

発光効率に関する研究は、かなり以前から世界各地で行われ、か なりの研究報告がある。しかし、これらの既往の研究に示されてい る発光効率は、かなり大まかな検討であったり、限られた条件の データによる検討であったりしている。このため、発光効率に関す る高精度で汎用性の高い式はいまだ提案されていないとしても過言 ではない。

本研究では、CIE 注1 の IDMP 注2で取得したデータに基つくく、水 平面全天日射量（水平面グローバル放射照度）と水平面グローバル 照度の関係、天空日射量（天空放射照度）と全天空照度の関係、直
達日射量（直達放射照度）と直射照度の関係を検郡し、日射量から 昼光照度を推定する方法として発光効率を考察した。加えて、筆者 らの IDMP の測定所で取得した実測データにより、入手が比較的容 易である日射量から冝光照度を推定する変換式を提案する。

\section{2. 発光効率の定䔐}

発光効率は、地表に到達する可視域の日射の分光エネルギー量に 分光視感度を乗じた值の累積、すなわち、昼光照度の、地表に到達 する日射量の全波長域のエネルギー量に対する比として、次式で定 義される。

$$
\eta=K_{m} \cdot \int_{380}^{780} V(\lambda) \cdot I(\lambda) d \lambda / \int_{0}^{\infty} I(\lambda) d \lambda
$$

ここで、

$\eta:$ 発光効率 $[1 \mathrm{~m} / \mathrm{W}]$ 、

$K_{m}:$ 最大視感度 $[1 \mathrm{~m} / \mathbb{W}]^{\text {注 } 3}$ 、

$\lambda:$ 波長 $[\mathrm{nm}]$ 、

$V(\lambda):$ 標準比視感度 $[-]$ 注 4 、

$I(\lambda)$ : 波長 $\lambda$ における日射エネルギー $\left[\mathrm{W} / \mathrm{m}^{2} \cdot \mathrm{nm}\right] 、$ である。

すなわち、発光効率の特性は、日射が大気を透過して地表に到達 するときの、全波長域での消散と可視域での消散との関係が関与す る。

\footnotetext{
* 怢竹中工枒店技術研究所 主任研究員・工博

** 高知女子大学生活科学部 助手・家修

*** 高知女子大学生活科学部 教授. 工博
}

Chief Researcher, Research \& Development Institute, Takenaka Corp., Dr. Eng. Research Assoc., Faculty of Human Life and Environmental Science, Kochi Women's University, M. H.E.

Prof., Faculty of Human Life and Environmental Science, Kochi Women's University, Dr. Eng. 


\section{3. 日射量と冝光照度に関する予備的検討}

尽光照度は、地表面に到達する日射量を視感度で補正した量であ る。大気を透過する日射の減衰の波長に対する依存性は、大気の状 態により異なる。このため、日射量に対する昼光照度の比である発 光効率は固定した一定の值とはならない。

発光効率については、近年、本邦の内外で研究されている。 Littlefair, P. J.は 1958 年から 1984 年までの間に世界各地で公表さ れた研究成果をレビューしている4。そこに記載されている文献に はそれぞれ異なった発光効率が示されている。その他、最近の発光 効率に関するいくつかの研究もある $5,6,7,8,9,10$ 。しかし、いずれにも 定説とするに值する知見はない。

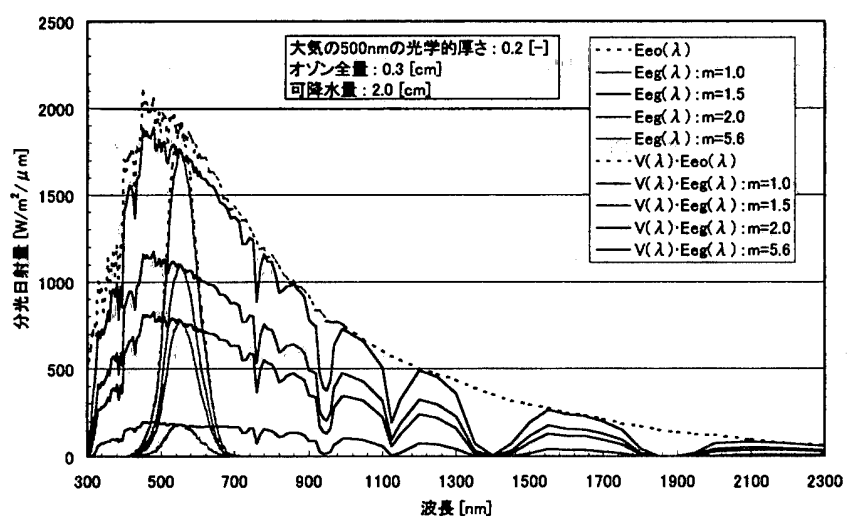

图 1 大気路程別の分光水平面全天日射睡と、CIE 標準比視感 度と分光水平面全天日射量の稪

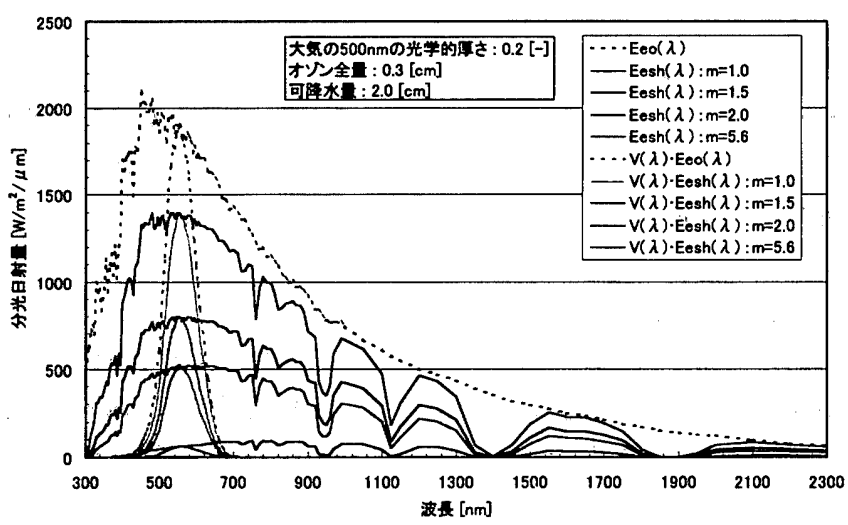

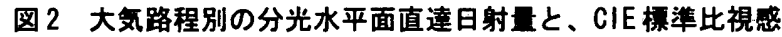
度と分光水平面直達日射量の程

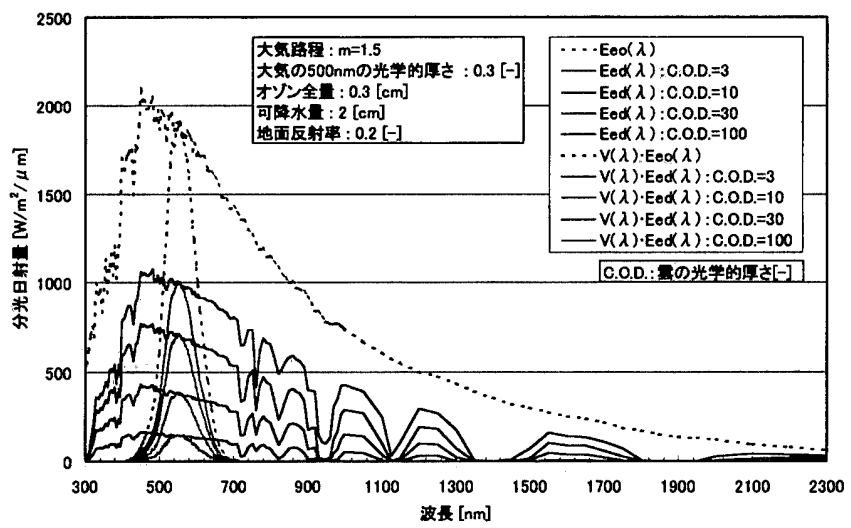

图 3 塞の光学的厚さ別の分光天空日射量と、CIE 栖染比視感 度と分光天空日射量の栍
CIE の Technical Report ${ }^{11}$ には、大気外分光日射量にあわせて、 地表における日射の分光特性についての基礎的データが、大気路程 や雲の光学的厚さなどの条件別に示されている。この中に、波長 $300 \mathrm{~nm}$ から $2,300 \mathrm{~nm}$ の日射量のモデル化した分光特性データがあ る。限られた波長域の資料であるが、これに基づき、日射量と冝光 照度のおおよその関係を予備的に検討する。

図 1 に、大気外分光日射量と、大気路程 $\mathrm{m}^{\text {住 }} 5$ を $1.0 、 1.5 、 2.0$ 、 5.6 としたときの地表における分光水平面全天日射量 $\operatorname{Eeg}(\lambda)$ 、それ らと CIE 標準比視感度との積 $V(\lambda) \cdot \operatorname{Eeg}(\lambda)$ 、を示す。分光水平面全 天日射量の全波長域の積分值は水平面全天日射量である。分光水平 面全天日射量と CIE 標淮比視感度の積の可視域での積分值に最大視 感度を乗じると水平面グローバル照度が求まる。これによりグロー バル照度に関する発光効率を推定する。

図 2 に、大気外分光日射量と、大気路程 $\mathrm{m}$ を $1.0 、 1.5 、 2.0$ 、 5.6 としたときの地表にお打る分光水平面直達日射量 $\operatorname{Eesh}(\lambda)$ 、そ れらと CIE 標準比視感度との積 $V(\lambda) \cdot \operatorname{Eesh}(\lambda)$ 、を示す。分光水平面 直達日射量と、分光水平面直達日射量と CIE 標淮比視感度と最大視 感度により、水平面直達日射量と水平面直射照度を求め、直射照度 に関する発光効率を推定する。

図 3 に、大気外分光日射量と、地表面の反射率を 0.2 、雲の光学 的厚さ注 6 を $3 、 10 、 30 、 100$ としたときの地表面における分光天空 日射量 $\operatorname{Eed}(\lambda)$ 、それらと CIE 標淮比視感度の積 $V(\lambda) \cdot \operatorname{Eed}(\lambda)$ 、を示 す。分光天空日射量と、分光天空日射量と CIE 標準比視感度と最大 視感度により、天空日射量と全天空照度を求め、全天空照度に関す る発光効率を推定する。

図 4 に、グローバル照度と水平面直射照度の大気路程に関する発 光効率を示す。グローバル照度の発光効率は $105 \sim 115[1 \mathrm{~m} / \mathrm{W}]$ 、直 射照度の発光効率は $70 \sim 110[1 \mathrm{~m} / W]$ の範囲にある。大気路程に関

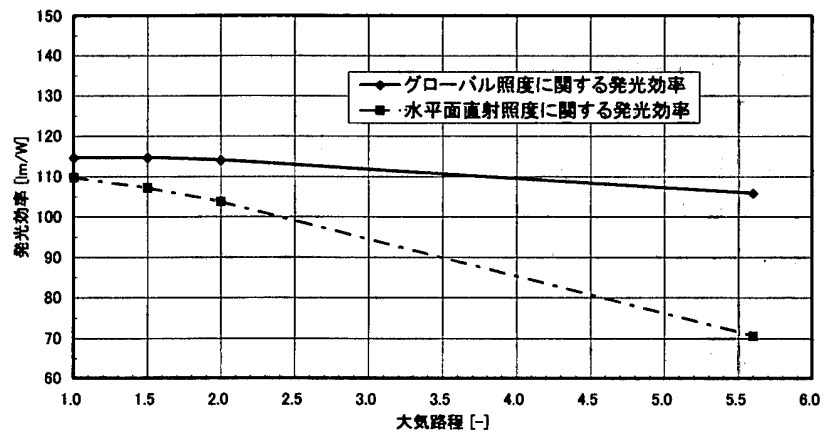

図 4 水平面照度の大文路程に関する発光效率

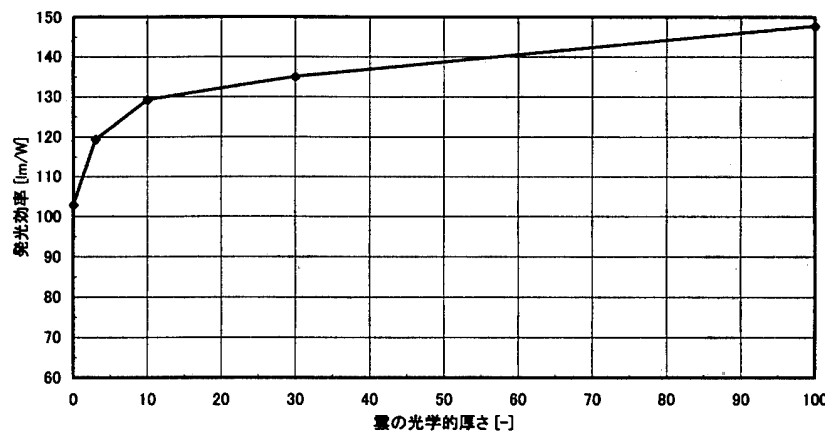

図 5 全天空照度の雲の光学的厚さに関する発光効率 
わらず、グローバル照度に関する発光効率の方が直射照度に関する 発光効率より大きいようである。この二つの発光効率は大気路程が 大きくなるほど小さくなるようである。すなわち、太陽高度が低く なるほど小さくなると考えられる注7。

図 5 に全天空照度の雲の光学的厚さに関する発光効率を示す。全 天空照度に関する発光効率は $110 \sim 150[\mathrm{~lm} / \mathrm{W}]$ の範囲にあり、雲の 光学的厚さが大きくなるほど大きくなるようである。

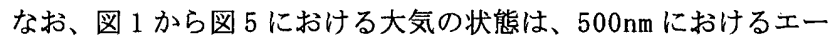
ロゾルの光学的厚さ裎 8 が 0.2 、オゾン全量往 9 が $0.3 \mathrm{~cm}$ 、可降水量注 10 が $2.0 \mathrm{~cm}$ である。

以上は限られた条件での検討である。すべての条件での発光効率 を表しているわけではないが、発光効率は固定した一定值ではな く、大気路程の関数として、また、雲の光学的厚さと関連した日射 量の関数であることを示唆している。

\section{4. 発光効率の推定}

一般的に、大気の状態は大気透過率や混濁因子などを指標として 表す。しかし、これらの指標はいずれも直達日射量や直射照度が得 られるときのみに有効な指標であり、疃天時には適用できない。す なわち、直射光があるときの大気の状態だけを表しているに過ぎな い。大気の污染状態を発光効率の指標としていることもある。さら に、大気の湿度なども組み合わせて指標としている場合もある。晴 天や量天の別、季節や月などを指標として発光效率を表している例 もある。いずれにしても、相当に大まかな指標であり、大気の状態 を詳紐かつ適切に表わしているとは思えない。汎用的、実用的で簡 易な指標が必要である。

\section{1 実測資料の収集とその整理}

CIE 注1 の IDMP 注2 と連携して、(株) 竹中工務店（東京都江東区， $\left.139^{\circ} 39^{\prime} 04^{\prime \prime} \mathrm{E}, 35^{\circ} 40^{\prime} 04^{\prime \prime} \mathrm{N}\right)$ では 1992 年 3 月から昼光と日射 の測定を実施している。日射量と昼光照度の測定には、CIE の IDMP の測定法 ${ }^{12}$ に淮拠した精密全天日射計(MS-801：EK0) と照度計 (ML010S：EK0）を使用している。天空日射量と全天空照度の測定には、 直径 $500 \mathrm{~mm}$ 、幅 $25 \mathrm{~mm}$ の遮蔽リングを使用している。

発光効率の検討には、1992 年 3 月から 1993 年 9 月までの測定 で取得した、水平面全天日射量、天空日射量、直達日射量、水平面 グローバル照度、全天空照度、直射照度のデータを適用した。デー 夕数はそれぞれ約 20,000 個である。

発光効率の検討の資料とする日射量から推定する昼光照度は、日 射量と太陽高度の関数として表した。このため、測定で取得したそ れぞれの日射量と昼光照度を、太陽高度 $5^{\circ}$ から $75^{\circ}$ まで $5^{\circ}$ の幅 を帯域とする14 のグループに分けた。

\section{2 日射量から昼光照度を推定する変換式}

本研究では、日射量の実測データから昼光照度を推定する手法を 提案すること、したがって、日射量から昼光照度を推定する変換式 を提案することが肝要である。

発光効率は太陽高度や天空の状態によって恋化する。とくに、大 気路程は、日射が大気を透過するときの消散の程度と直接関連す る。したがって、発光効率を検討するには、実測で取得した日射量
と昼光照度のデータを、大気路程に関して整理することが必要であ る。大気路程は太陽高度の関数として表すことができるので、日射 量と昼光照度の関係を太陽高度の関数として表すことにする。

地表面で測定により取得した日射量や昼光照度は、日射が大気を 透過する過程における消散の影響を受けた結果である。すなわち、 任意の太陽高度における地表面の日射量は、そのときの大気による 消散の状況を総合的に示す最も直接的な指標と考える。

以上により、日射量から昼光照度を推定する変換式は、日射量と 太陽高度の関数として次のように表すことにする。

$$
E v=f\left(E e, \gamma_{s}\right) \quad[1 \mathrm{x}]
$$

ここで、

$$
\begin{aligned}
& E v \text { : 昼光照度 }[\mathrm{lx}] 、 \\
& E e: \text { 日射量 }\left[\mathrm{W} / \mathrm{m}^{2}\right] 、 \\
& \gamma_{s}: \text { 太陽高度 }[\mathrm{rad} .] 、
\end{aligned}
$$

である。

なお、太陽高度は高い精度で求めることが肝要である。太陽位置 の計算に必須の太陽の赤緯や均時差に関しては、比較的簡単で実用 上十分な精度を有している山崎による近似式 ${ }^{13}$ や若干複雑である が精度の高い海上保安庁による近似式 ${ }^{14}$ などがある。本研究では後 者を採用している。

\section{3 天空日射量による全天空照度の推定}

図 6 に、太陽高度帯 $30^{\circ}$ から $35^{\circ}$ のときの天空日射量と全天空 度の関係を例示する。他の太陽高度も参照すれば、天空日射量と全 天空照度にはかなり高い相関があるようである。全天空照度は天空 日射量の関数として表現できると考える。 天空日射量と全天空照度の関係を次式で表すことにする。 $E v d=a_{d} \cdot E^{D} d^{D}[\mathrm{Ix}]$ ここで、

$$
\begin{aligned}
& E v d: \text { 全天空照度 }\left[1 \mathrm{x}=1 \mathrm{~m} / \mathrm{m}^{2}\right] \text { 、 } \\
& \text { Eed : 天空日射量 }\left[\mathrm{W} / \mathrm{m}^{2}\right] 、 \\
& a_{d} 、 D: \text { 未確定項、 }
\end{aligned}
$$

である。

まず、基礎資料に基づき、太陽高度ごとに、式(3)による回㷌分

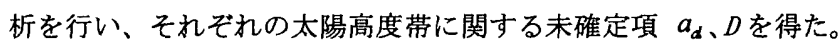
次いで、得られた未確定項 $D$ について、太陽高度の関数として回㷌 分析を行い、未確定項 $D$ を定数 0.9 とした。これを図 7 に示す。 次に、未確定項 $D に 0.9$ を代入して、再度、実測データに基づき 式(3)による回帰分析を試みた。それぞれの太陽高度帯に関して未 確定項 $a_{d}$ の值を得た。これを太陽高度の関数として回帰分析を重 ね、未確定項 $a_{d}$ について次式を得た。 $a_{d}=20.81 \cdot \gamma_{s}^{3}-86.57 \cdot \gamma_{s}^{2}+133.59 \cdot \gamma_{s}+158.40[-]$ 式(4)を図 8 に図示する。

以上により、全天空照度は天空日射量と太陽高度の関数として、 次式で推定できる。

$E v d=\left(20.81 \cdot \gamma_{s}^{3}-86.57 \cdot \gamma_{s}^{2}+133.59 \cdot \gamma_{s}+158.40\right) \cdot E^{2} d^{0.9}[1 \mathrm{x}] \cdots \cdots(5)$ 全天空照度に関する発光効率は、次式で推定できる。

$$
\eta_{d}=\frac{E v d}{E e d}=\left(20.81 \cdot \gamma_{s}^{3}-86.57 \cdot \gamma_{s}^{2}+133.59 \cdot \gamma_{s}+158.40\right) \cdot E^{-0.1}
$$


ここで、

$\eta_{d}:$ 全天空照度に関する発光効率 $[1 \mathrm{~m} / \mathrm{W}]$ 、

である。

\section{4 直连日射目による直射照度の推定}

図 9 に、太陽高度帯 $30^{\circ}$ から $35^{\circ}$ のときの直達日射量と直射照 度の関係を例示する。これによれば、直達日射量と直射照度にも かなり高い相関があるようである。直射照度も直達日射量の関数 として表現できると考える。

天空日射量と全天空照度の関係と同様に、直達日射量と直射照 度の関係を次式で表すことにする。

$E v s=a_{s} \cdot E^{s} \quad[1 \mathrm{x}]$

ここで、

Evs : 直射照度 $\left[1 \mathrm{x}=1 \mathrm{~m} / \mathrm{m}^{2}\right]$ 、

Ees : 直達日射量 $\left[\mathrm{W} / \mathrm{m}^{2}\right]$ 、

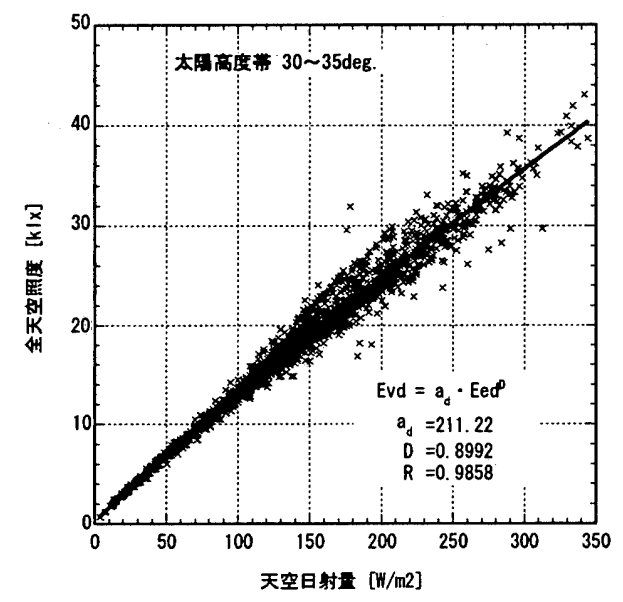

图 6 天空日射旦と全天空照度の関係

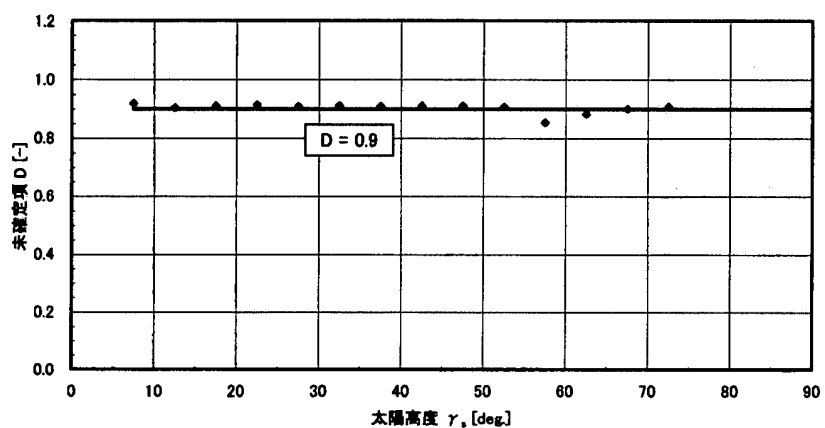

图 7 太淂高度と末確定項 Dの関係

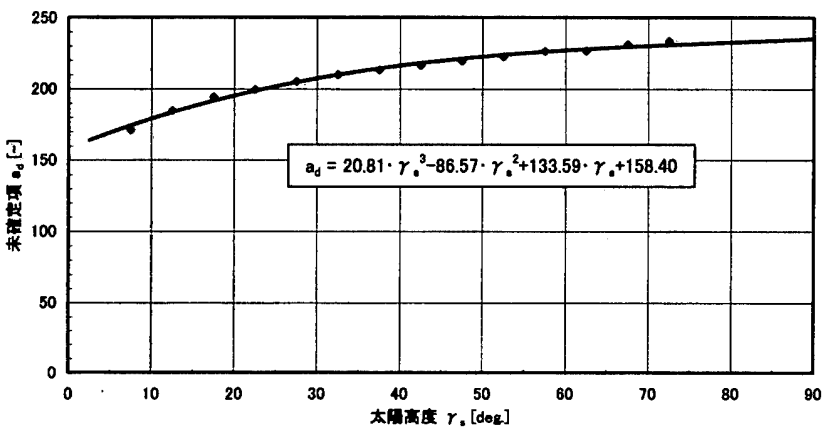

图 8 太陣高度と末確定项 $a_{d}$ の関係 $a_{s} 、 S:$ 未確定項、

である。

以下、天空日射量と全天空照度の時と同様にして、図 10 に示す ように未確定項 S を定数 1.1 とし、未確定項について次式を得た。

$$
a_{s}=-7.87 \cdot \gamma_{s}^{4}+40.56 \cdot \gamma_{s}^{3}-78.43 \cdot \gamma_{s}^{2}+68.05 \cdot \gamma_{s}+35.16 \quad[-] \cdots
$$

式(8)を図 11 に図示する。

以上により、直射照度は直達日射量と太陽高度の関数として、次 式で推定できる。

$E v s=\left(-7.87 \cdot \gamma_{s}^{4}+40.56 \cdot \gamma_{s}^{3}-78.43 \cdot \gamma_{s}^{2}+68.05 \cdot \gamma_{s}+35.16\right) \cdot$ Ees $^{1.1}[1 \mathrm{x}](9)$ 直射照度に関する発光効率は、次式で推定できる。

$\eta_{s}=\frac{E v s}{E e s}=\left(-7.87 \cdot \gamma_{s}^{4}+40.56 \cdot \gamma_{s}^{3}-78.43 \cdot \gamma_{s}^{2}+68.05 \cdot \gamma_{s}+35.16\right) \cdot$ Ees $^{0.1}$

ここで、

$\eta_{s}$ ：直射照度に関する発光効率 $[1 \mathrm{~m} / \mathrm{W}]$ 、

である。

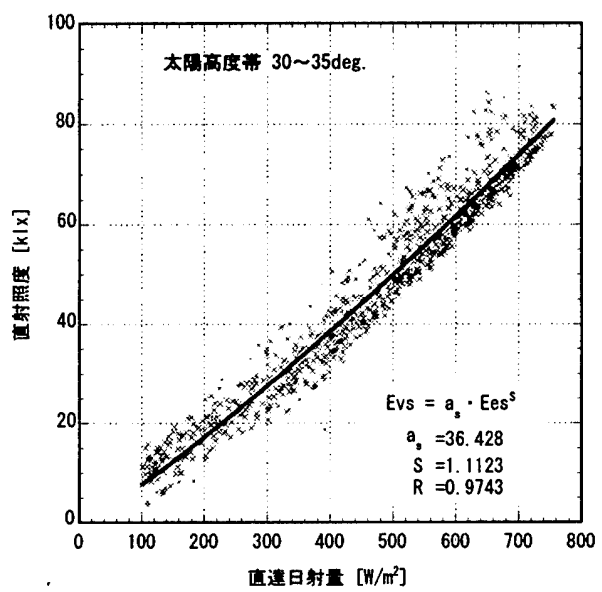

图 9 直達日射量と直射照度の関係

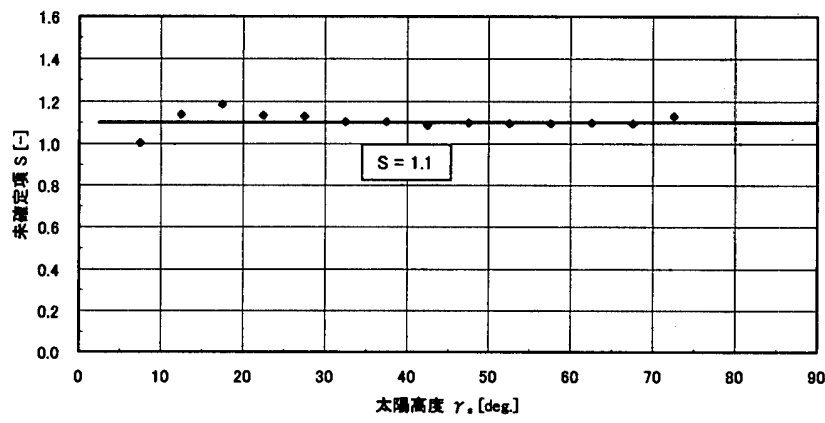

图 10 太晴高度と末確定项 $S$ の関係

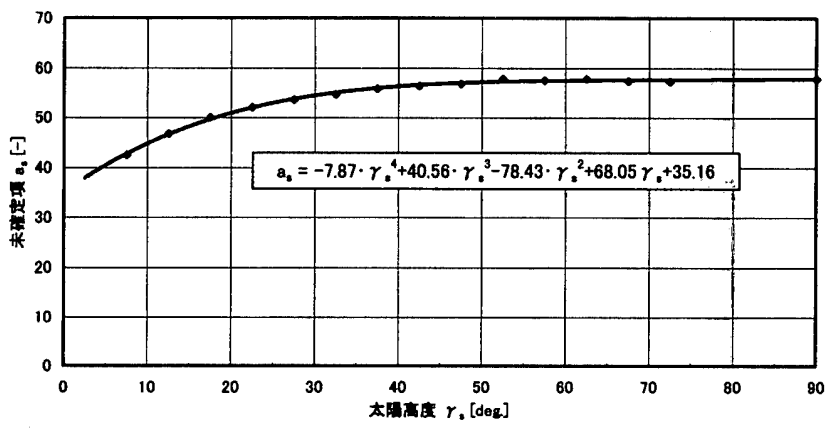

图 11 太晴高度と末確定项 $a_{s}$ の関係 


\section{5 水平面全天日射量と水平面グローバル照度の関係}

図 12 に、太陽高度帯 $30^{\circ}$ から $35^{\circ}$ のときの水平面全天日射量 と水平面グローバル照度の関係を例示する。他の高度带も参照すれ ば、水平面全天日射量と水平面グローバル照度にもかなり高い相関 があるようである。

水平面グローバル照度は、その值が小さいときは全天空照度の、 大きいときは直射照度の特性が支配的と考えられる。したがって、 水平面全天日射量と水平面グローバル照度の関係は、天空日射量と 全天空照度の関係 $\left(E v d=a_{d} \cdot E e d^{1.1}\right)$ と、直達日射量と直射照度の関 倸 $\left(E v s=a_{s} \cdot E v s^{0.9}\right)$ の加重和と考え、次式で表すこととした。

$E v g=a_{g 1} \cdot E^{0} g^{0.9}+a_{g 2} \cdot E^{1.1} \quad[1 \mathrm{x}]$

ここで、

$E v g$ : 水平面グローバル照度 $\left[1 \mathrm{x}=1 \mathrm{~m} / \mathrm{m}^{2}\right]$ 、

$E e g$ : 水平面全天日射量 $\left[\mathrm{W} / \mathrm{m}^{2}\right]$ 、

$a_{g 1} 、 a_{g 2}:$ 未確定項、

である。

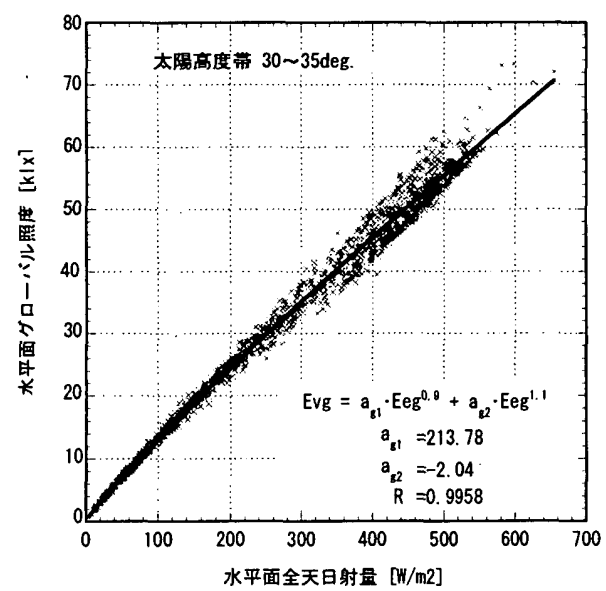

図 12 全天日射量とグローバル照度の関係

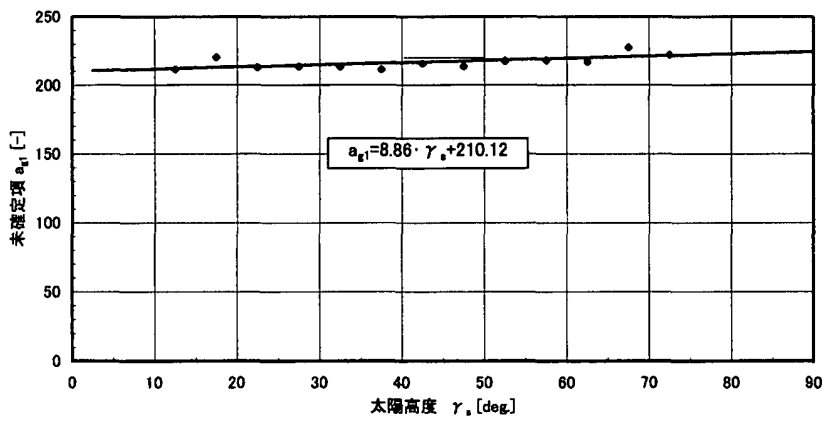

図 13 太陽高度と未確定項 $a_{g 1}$ の関係

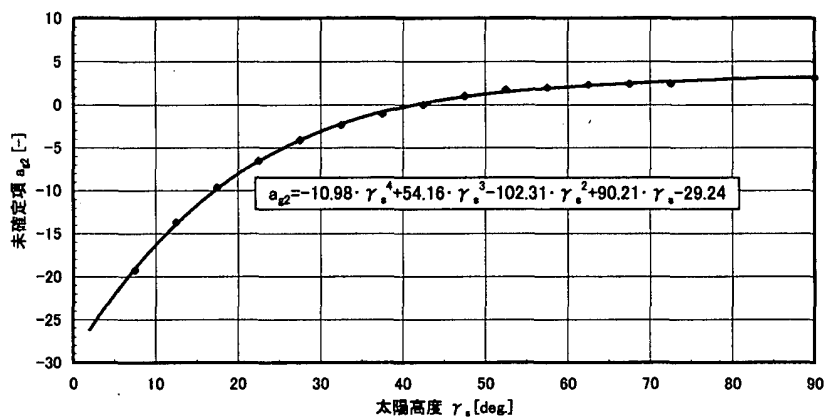

図 14 太陽高度と未確定項 $a_{g^{2}}$ の関係
前項と同様に、未確定項 $a_{g 1}$ 、未確定項 $a_{g 2}$ を次のように得た。

$a_{g 1}=8.86 \cdot \gamma_{s}+210.12$

$a_{g 2}=-10.98 \cdot \gamma_{s}^{4}+54.16 \cdot \gamma_{s}^{3}-102.31 \cdot \gamma_{s}^{2}+90.21 \cdot \gamma_{s}-29.24$

式(12) と式(13)を図 13、図 14 に図示する。

以上により、水平面グローバル照度は、水平面全天日射量と太陽 高度の関数として、次式で推定できる。

$E v g=\left(8.86 \cdot \gamma_{s}+210.12\right) \cdot E^{0.9}$

$$
+\left(-10.98 \cdot \gamma_{s}^{4}+54.16 \cdot \gamma_{s}^{3}-102.31 \cdot \gamma_{s}^{2}+90.21 \cdot \gamma_{s}-29.24\right) \cdot \text { Eeg }^{1.1}
$$

水平面グローバル照度に関する発光効率は、次式で表せる。

$$
\begin{aligned}
\eta_{g} & =\frac{E v g}{E e g} \\
& =\left(8.86 \cdot \gamma_{s}+210.12\right) \cdot E^{-0.1} \\
& +\left(-10.98 \gamma_{s}^{4}+54.16 \gamma_{s}^{3}-102.31 \gamma_{s}^{2}+90.21 \gamma_{s}-29.24\right) \cdot \text { Eeg }^{0.1}
\end{aligned}
$$

$[\mathrm{lm} / \mathrm{W}]$

ここで、

$\eta_{g}:$ 水平面グローバル照度に関する発光効率 $[1 \mathrm{~m} / \mathrm{W}]$ 、 である。

\section{6 太陽高度や日射量と発光効率の関係}

式(6)、式(10)、式(15)に示した発光効率について、日射量と太 陽高度との関倸を整理して図 15 から図 17 に示す。

図 15 に示す全天空照度に関する発光効率は、太陽高度が高いほ ど大きい。また、天空日射量が小さいほど発光効率は大きい。すな わち、雲の光学的厚さが薄いほど発光効率が小さくなる傾向を示し ている。

図 16 に示す值射照度に関する発光効率も、太陽高度が高いとき ほど大きい。しかし、全天空照度に関する発光効率と異なり、一般 に直達日射量が小さいほど発光効率は小さい。この傾向は太陽高度 が $30^{\circ}$ から $40^{\circ}$ 以上のとき顕著になる。最小值は $60 \sim 70[1 \mathrm{~m} / \mathrm{W}]$ で図 3 に示した CIE の Technical Report ${ }^{n}$ の推奨值に基づく推定值 とほぼ一致している。

図 17 に示す水平面グローバル照度に関する発光効率も太陽高度 が高くほど大きい。また、全天空照度関する発光効率と同様に、全 天日射量が小さいほど発光効率は大きい傾向がある。

以上は、前述の「3．日射量と昼光照度に関する予備的検討」の 結果とかなりよく一致している。また、発光効率に関する既往の研 究における種々の発光効率の提案值をほほ包含している。

\section{5．日射量から冝光照度を推定する変換式の検討}

本研究で提案する日射量から照度を推定する変換式の妥当性を検 討する。回帰分析に使用した実測データを用い、測定で直接取得し た昼光照度と日射量から推定した昼光照度を比較する。

図 18 に、太陽高度帯 $10^{\circ}$ から $15^{\circ} 、 30^{\circ}$ 加 $35^{\circ} 、 50^{\circ}$ から $55^{\circ}$ のとき、実測で直接取得した全天空照度と、同時に取得した天 空日射量から式(5)で推定した全天空照度との比較を例示する。い ずれの場合も高い相関を示している。

図 19 に、図 18 と同様に実測で直接取得した直射照度と、同時 に取得した直達日射量から式 (9) で推定した直射照度との比較を例 示する。全天空照度に関する図 18 と比較すると、太陽高度が低い とき、ややばらつきはあるが、全体的には高い相関を示している。 


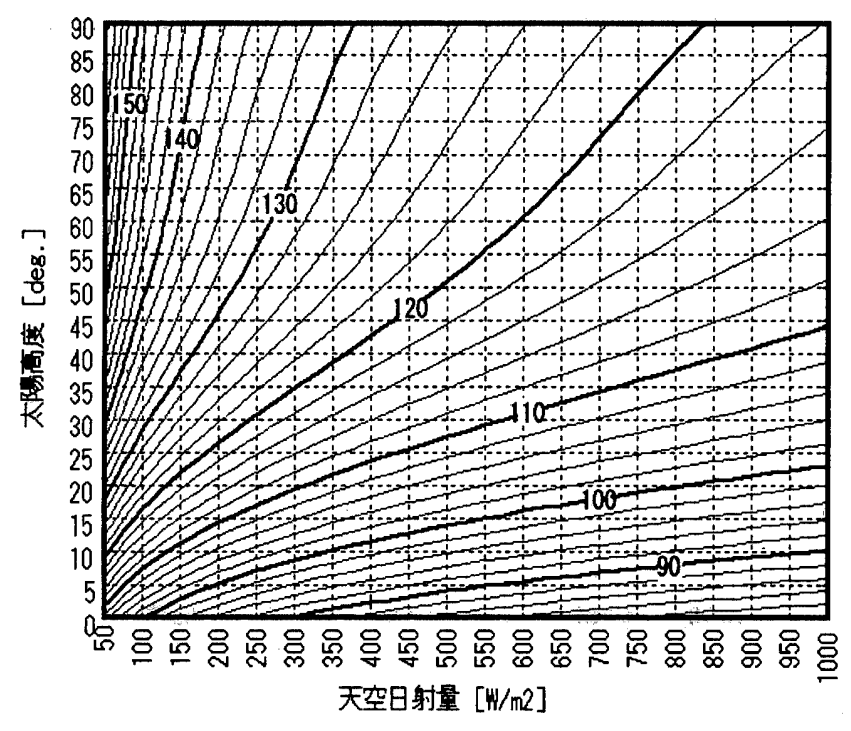

图 15 全天空照度に関する発光勃率 $: \eta_{d}[1 \mathrm{~m} / \mathrm{W}]$

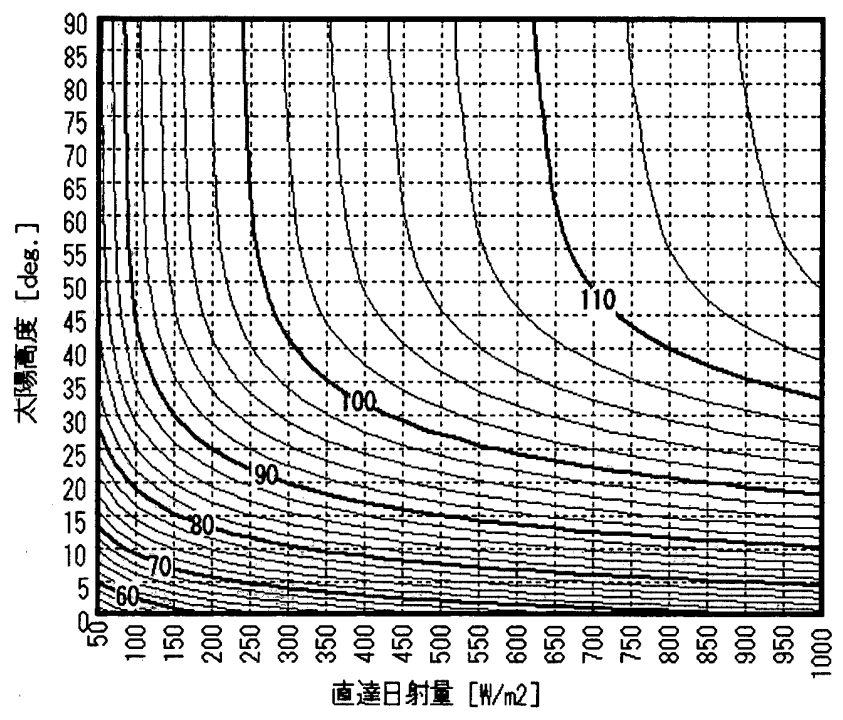

图 16 直射照度に関する発光效率 : $\eta_{s}[1 \mathrm{~m} / \mathrm{W}]$

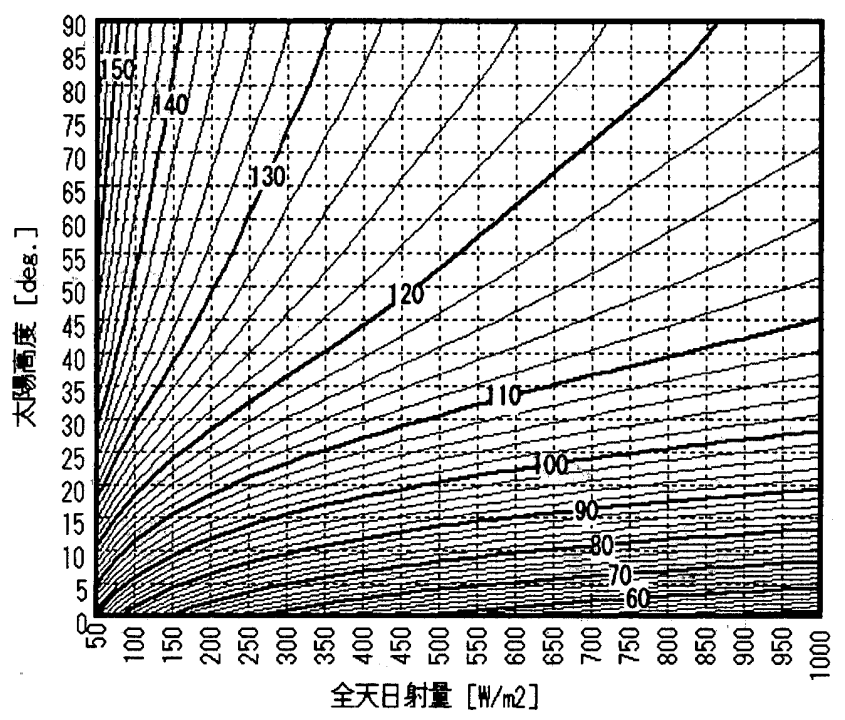

图 17 グローバル照度に関する発光効率 : $\eta_{g}[\mathrm{~lm} / \mathrm{W}]$
表 1 实測で取得した昼光照度と日射量から推定した昼光照度の 太陵高度带別の相関係数

\begin{tabular}{|c|c|c|c|}
\hline 太陽高度带 & $\begin{array}{l}\text { 全天空照度|二関す } \\
\text { る相関係数 } \\
\end{array}$ & $\begin{array}{l}\text { 直身照度に二関する } \\
\text { 相関係数 }\end{array}$ & $\begin{array}{l}\text { グローバル照度に } \\
\text { 関する相開係数 }\end{array}$ \\
\hline [deg] & {$[-]$} & {$[-]$} & {$[-1$} \\
\hline $5 \sim 10$ & 0.9781 & 0.7152 & 0.9817 \\
\hline $10 \sim 15$ & 0.9712 & 0.8931 & 0.9819 \\
\hline $15 \sim 20$ & 0.9778 & 0.9266 & 0.9813 \\
\hline $20 \sim 25$ & 0.9786 & 0.9527 & 0.9944 \\
\hline $25 \sim 30$ & 0.9716 & 0.9654 & 0.9950 \\
\hline $30 \sim 35$ & 0.9854 & 0.9740 & 0.9959 \\
\hline $35 \sim 40$ & 0.9840 & 0.9770 & 0.9958 \\
\hline $40 \sim 45$ & 0.9867 & 0.9792 & 0.9960 \\
\hline $45 \sim 50$ & 0.9871 & 0.9781 & 0.9956 \\
\hline $50 \sim 55$ & 0.9854 & 0.9810 & 0.9958 \\
\hline $55 \sim 60$ & 0.9765 & 0.9787 & 0.9954 \\
\hline $60 \sim 65$ & 0.9630 & 0.9767 & 0.9952 \\
\hline $65 \sim 70$ & 0.9747 & 0.9775 & 0.9962 \\
\hline $70 \sim 75$ & 0.9829 & 0.9805 & 0.9976 \\
\hline
\end{tabular}

図 20 に、図 18 や図 19 と同様に実測で直接取得した水平面グロー バル照度と、同時に取得した水平面全天日射量から式(14)で推定し た水平面グローバル照度との比較を例示する。

表 1 に、実測により直接取得した昼光照度と日射量から推定した 昼光照度の相関係数を太陽高度別に示す。ほとんどで 0.9 以上の高 い相関係数となっている。

以上、実測により直接取得した冝光照度と日射量から推定した昼 光照度は、全体的に非常に高い相関を示していると考える。

次に、気象庁の 1995 年のデータにより、日射量の昼光照度への 変換を試みた。ここでは、札幌、東京、福岡の気象庁のデータによ る変換例を示す。

まず、各地域の水平面全天日射量を直散分離して、直達日射量と 天空日射量を求めた。直散分離については、兽我、赤坂らにより各

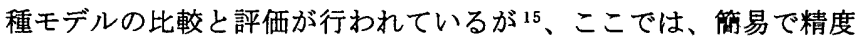
の高いとされる Skartveit, A. らによる式 ${ }^{16}$ で直散分離を行った。続 いて、水平面全天日射量、直達日射量、天空日射量を式(5)、式(9)、 式(14)により、水平面グローバル照度、直射照度、全天空照度に変 換した。さらに直射照度から水平面直射照度を求め、これと全天空 照度により水平面グローバル照度を合成した。図 21 に、各地域に おける、合成した水平面グローバル照度と水平面全天日射量から変 換した水平面グローバル照度の関係を示す。両者は、いずれの地域 においても、ほぼ同一であり、その相関係数は 0.999 以上である。 すなわち、本研究で提案する日射量から昼光照度を推定する変換式 は、そのそれぞれの相互の整合性が高い。また、個別に適用するこ とが可能であることも示している。

以上、式(5)、式(9)、式(14)は、いずれも日射量から昼光照度 を推定する変換式として、十分に実用に供し得ると考える。

\section{6. まとめ}

本邦では、昼光に関する定常的な測定は、IDMP の測定以外に、 ほとんど実施されていない。最も容易に入手できる太陽放射に関す 

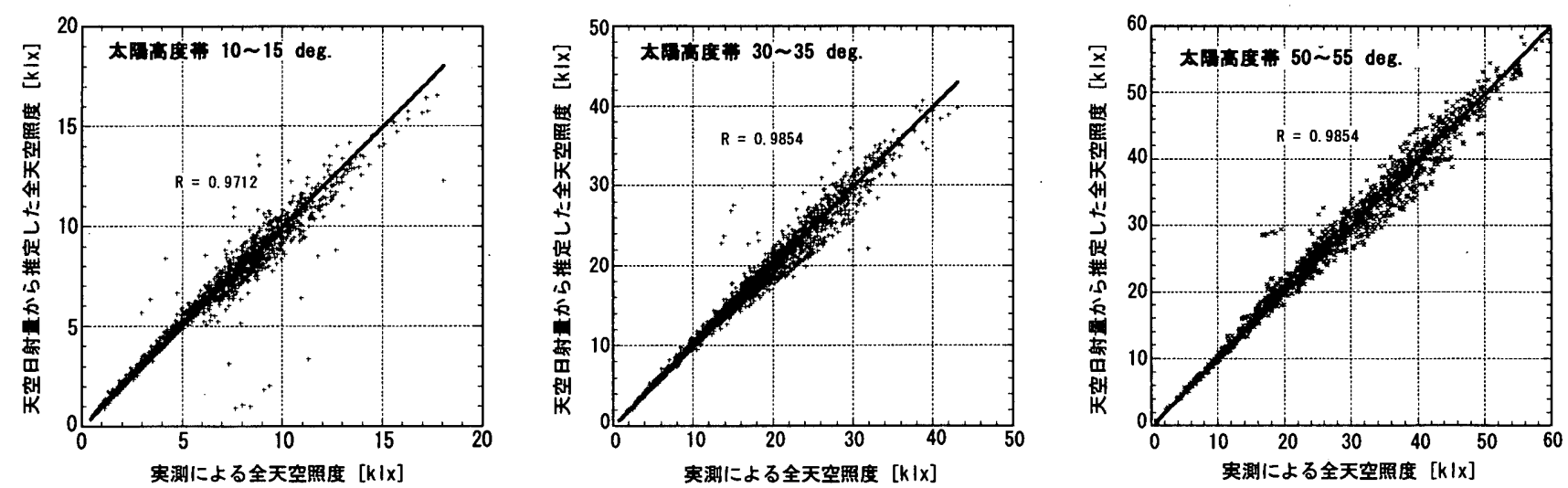

图 18 実測で取得した全天空照度と、式 (5) で天空日射量から推定した全天空照度の比較例
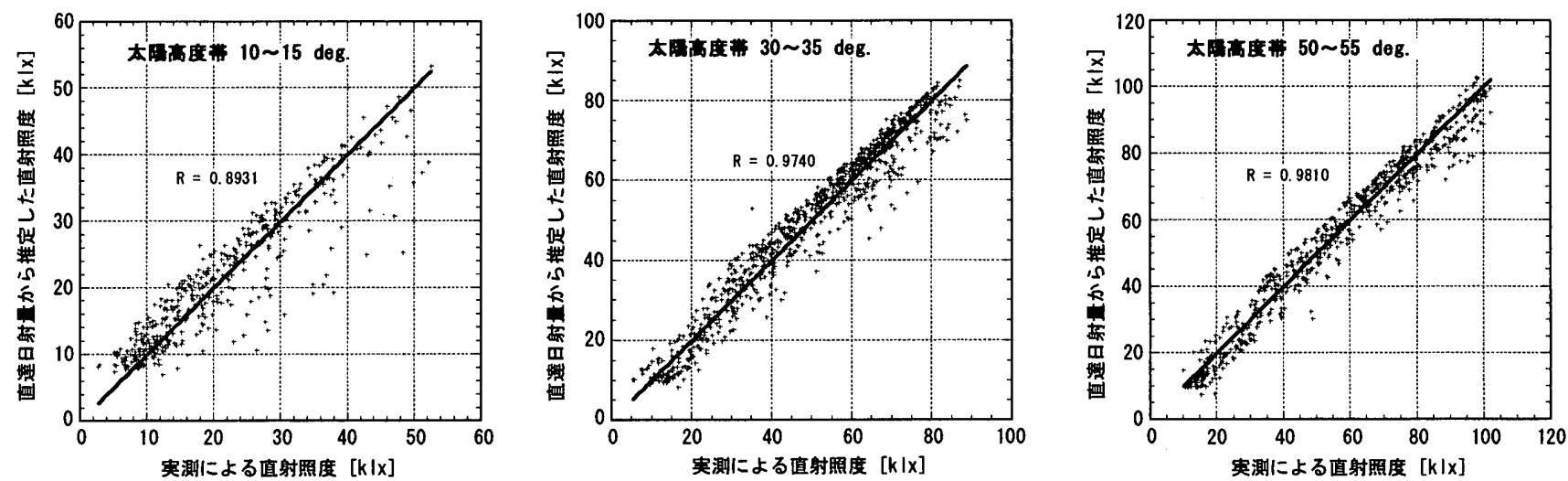

図 19 実測で取得した直射照度と、式(9)で直達日射量から推定した直射照度の比較例
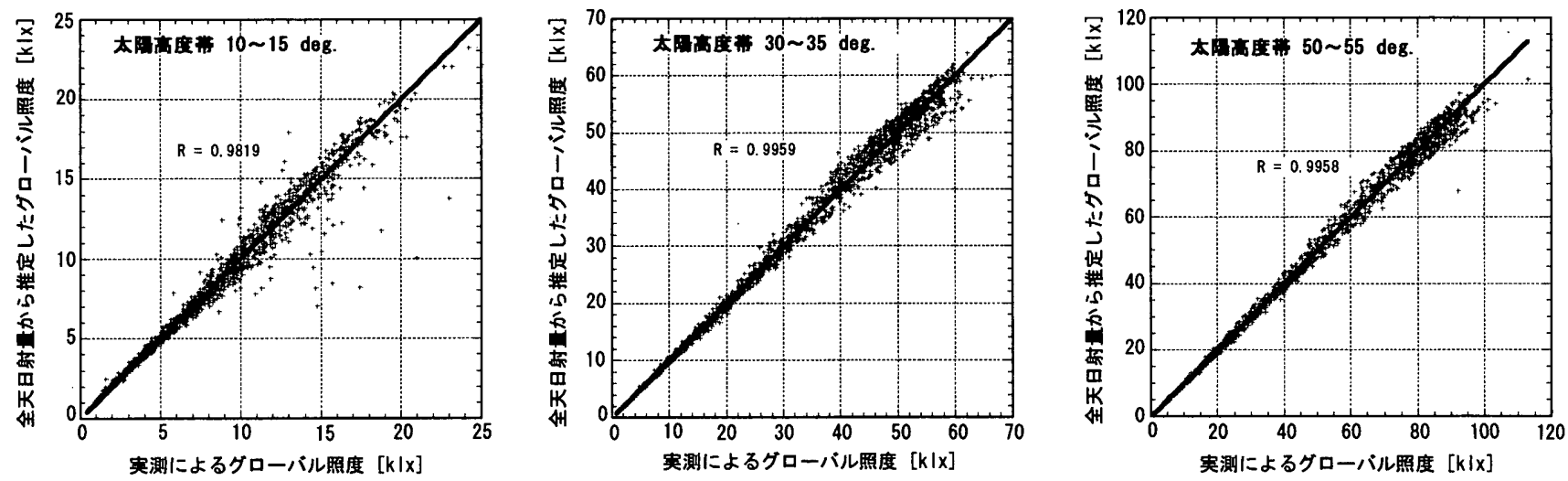

图 20 実測で取得した水平面グローバル照度と、式(14) で水平面全天日射嘼から推定した水平面グローハル照度の比較例
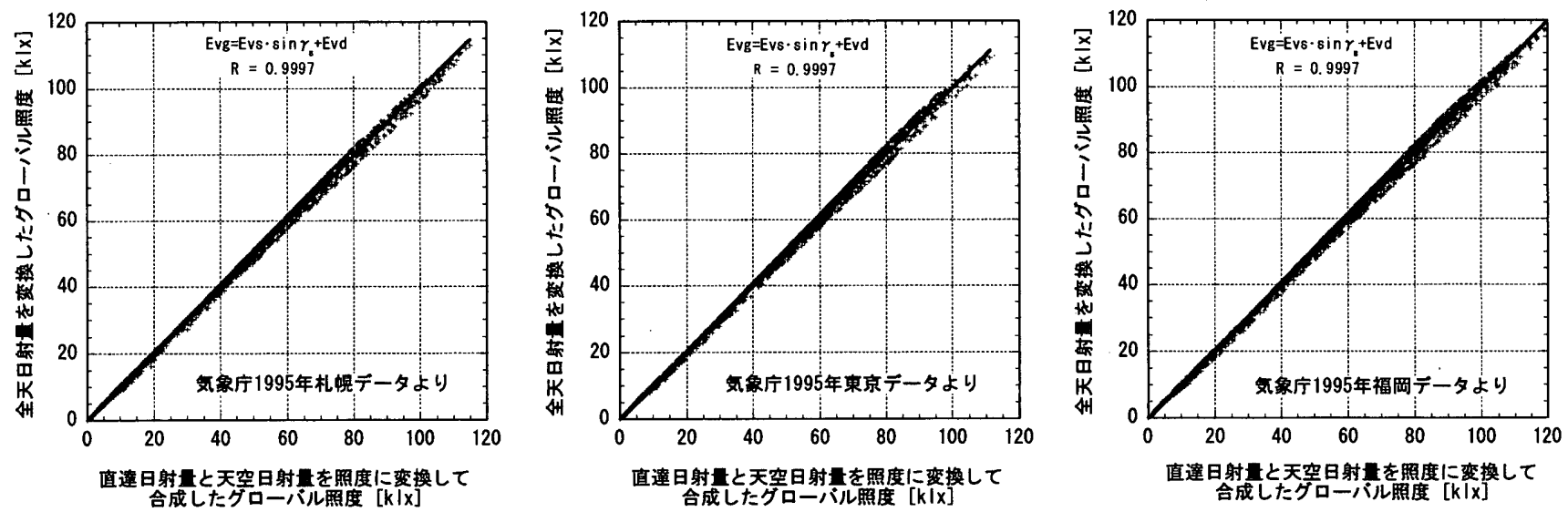

图 21 水平面全天日射量の直散分離による直達日射量と天空日射量から推定した直射照度と全天空照度を合成した水平面グローバル 照度と、水平面全天日射量から推定した水平面グローバ照度の関係（気象庁 1995 年の、札幌、東京、福岡のデータによる） 
る実測データは、気象台で 1 時間ごとに測定している水平面全天日 射量である。したがって、日射量から昼光照度を推定するための、 高精度で汎用的な変換式が不可欠である。このため、本研究では、 日射量と昼光照度の実測データを基に、日射量から冝光照度を推定 する方法を検討し、次の結果が得られた。

(1) 天空日射量、直達日射量、全天日射量とその時の太陽高度から、 全天空照度、直射照度、グローバル照度をそれぞれ推定できる変換 式を提案することができた。

(2) 提案した日射量から昼光照度を推定する変換式の構造はさほど 複雑ではない。

（3）変換式は各種気象データに含まれる日射量のデータに容易に適 用可能である。

（4）日射量から推定した昼光照度と実測で取得した昼光照度の相関 は高く、実用的に十分な精度を有していることが確認できた。

すなわち、本研究の成果により、あらゆる天空状態において、日 射量により昼光照度を容易に推定することが可能になった。また、 省エネルギーや室内環境の質をも考虑した、温熱環境や昼光環境の 予測評価や実際の計画、設計に有用な精度の高い資料の入手が容易 になった。以上、本研究は建築環境工学の発展と向上に大きく寄与 するものと信じる。

\section{注舐}

注 1) CIE: Commission Internationale de l'Eclairage（国際照明委員 会)、照明に関する基準や標準を定めたり、これらを勧告したり、 また、研究の交流を計る国際機関で、照明関倸の ISO 規格の原案も 作成している。100 年の歴史を誇り、現在、先進国を中心に約 40 ケ 国余が加盟している。

注 2) IDMP: International Daylight Measurement Programme (国際 昼光測定プログラム)、化石エネルギーに代替すべき自然エネル ギーである亩光や日射に関し、その実態を示す資料がそしい現況を 聂えた CIE が 1983 年に開始した世界的規模での昼光と日射の実測 資料の収集と整備の活動である。この実施のために CIE は技術委員 会 TC3-25を設けている。1991 年頃以降から、本邦に開設された 12 ヶ所の測定所を始め、世界各地に約 50 ヶ所の測定所が設膡さ れ、常時 1 分ごとのデータを測定している。共著者の中村は、1998 年まで TC3-25 の委員長を務め、以後、委員である。井川も委員を 務めている。http://idmp.entpe.fr/ 参照。

注 3) 最大視感度は、周波数 $540 \times 10^{12} \mathrm{~Hz}$ の単色光(空気中の波長 で $555 \mathrm{~nm}$ ）に対する視感度である。量記号 $K m$ で表し、その值は、 近年、 $683[1 \mathrm{~m} / \mathrm{W}]$ とされている。標準比視感度の基準とされてい る。

注 4）分光視感度の最大視感度に対する比を比視感度という。国際 照明委員会 (CIE) は明所視と暗所視における平均的な比視感度とし て標淮比視感度を定めている。一般的に比視感度といえば、明所視 の標準比視感度のことを指す。量記号 $V(\lambda)$ で表す。(CIE $19882^{\circ}$ Spectral Luminous Efficiency Function for Photopic Vision 参照)。 注 5）大気路程 m は、日射が大気を透過して地表に到達するまでの 空気量を、太陽が天頂にあるときの空気量を 1 とする相対值であ る。太陽高度の関数として表せるとし、Kittler, R. は下式を提案 している。

$$
m=2 \cdot\left(\sqrt{\sin ^{2} \gamma_{s}+0.0031465}-\sin \gamma_{s}\right) / 0.0031465[-]
$$

注 6）雲の光学的厚さ $\tau$ は、雲による日射の減衰の度合いを示す 指標で、雲により日射が $e^{-\tau} に$ に減衰することを意味する。

注 7）Kittler,R. の式(注 5)に見られるように、太陽高度が低いほ ど、大気路程は一般的に大きい。
注 8) エーロゾルの光学的厚さは、エーロゾルによる混濁度 (消散 の度合い)を示す指標で、光を減衰させる媒質の密度を $\rho$ 、単位質 量あたりの消散係数を $s(\lambda, x)$ とすると、大気全層のエーロゾルの光 学的厚さは、 $s(\lambda)=\int_{0}^{\infty} s(\lambda, x) \rho d x$ で表わせる。 $s(\lambda)=0.1$ がリンケの 混濁因子 2.8 (晴天空) に相当する。

注 9）オゾン全量 $[\mathrm{cm}]$ は、地上から上空にあるすべてのオソン分 子を集め、標準状態で換算したときの厚さで示す。オソン全量は、 地球上の場所や季節などで異なり、北緯 $80^{\circ}$ から北緯 $90^{\circ}$ の 3 月 頃に最も多く $0.44 \mathrm{~cm}$ 程度、赤道付近が最も少なく $0.26 \mathrm{~cm}$ 程度で ある。

注 10）可降水量 $[\mathrm{cm}]$ は、大気中の水蒸気量を表す指標で、地上 に鉛直に立てた気柱に含まれる全水蒸気量を水の量に換算したとき の厚さで示す。

\section{参考文献}

1 二宮秀與、赤坂裕、須貝高、黒木荘一郎、AMeDAS のデータを 用いた時刻別日射量の推定法、空気調和・衛生工学会論文集、 No. 39、pp. 13-23、1989.

2 二宮秀與、赤坂裕、松尾陽、兽我和弘、AMeDAS のデータを用 いた時刻別日射量の推定法、第 2 報 回転式日照計および改良型太 陽電池式日照計への適用、空気調和・衛生工学会論文集、No. 65 、 pp. 53-65、1997.

3 赤坂裕、建築環境評価のための AMeDAS 版時刻別気象データの 作成、平成 8 年度文部省科学研究費補助金 (基盤研究 A) 研究成果報 告書、1998.

4 Littlefair, P. J., The Luminous Efficacy of Daylight: a Review, Lighting Research \& Technology, Vol. 17, No. 4, pp.162-182, 1985. 5 宿谷昌則、木村建一、昼光の発光効率による每時水平面日射量か らの照度の推定、日本建築学会論文報告集、第 293 号、pp. 8595,1980 .

6 Littlefair, P.J., Measurements of the Luminous Efficacy of Daylight, Lighting Research \& Technology, No. 20, pp.177-188, 1988.

7 Koga, Y., Nakamura, H., Oki, M., Matsuzawa, T., Rahim, M.M., Study on Luminous Efficacy - The Relation to Cloud Ratio, LUX EUROPA 1993, Edinburgh, pp. 799-803, 1993.

8 Molineaux, B., Ineichen, P., Delaunay, J.J., Direct Luminous Efficacy and Atmospheric Turbidity Improving Model Performance, Solar Energy, Vol.55, No.2, pp.125-137, 1995.

9 Darula, S., Kittler, R., Daylighting Availability after One-minute Measurements for Energy Conscious Design, Proc. Conf. Building Physics Symposium, pp.243-248, 1995.

10 Chandra, M., Luminous Efficacy of Solar Radiation and Evaluation of Natural Illumination - a Review, Energy Convers. Mgmt., No.11, pp.1623-1634, 1996.

11 Solar Spectral Irradiance, Technical Report, Pub. No CIE 85, ISBN 390073422 4, pp. 1-43, 1989.

12 Guide to Recommended Practice of Daylight Measurement, Technical Report, Pub. No CIE 108, ISBN 2900073450 X, pp. 1-49, 1994. 13 山崎均、日照環境のための基礎式、日本建築学会計画系論文集、 第 288 号、pp. 139-146、1980。

14 太陽位置略算式、天測略歴、海上保安庁、pp. 1s-2s、1987。 15 曽我和弘、赤坂裕、二宮秀與、全天日射量から直達日射量と天 空日射量を推定する各種モデルの比較と評価、日本建築学会計画系 論文集、第 512 号、pp. 17-27、1998。

16 Skartveit, A., Olseth, J.A, A model for the diffuse fraction of hourly global radiation, Solar Energy Vol.38, No. 4, pp. 271-274, 1987.

（1999年 5 月 7 日原稿受理，1999年 8 月 2 日採用決定） 